\title{
Modification of spin crossover behavior through solvent assisted formation and solvent inclusion in a triply interpenetrating 3D network
}

Matthias Bartel, ${ }^{\dagger}$ Alina Absmeier, ${ }^{\dagger}$ Guy N. L. Jameson, ${ }^{* \neq}$ Franz Werner, ${ }^{\S}$ Kenichi Kato, ${ }^{\#}$ Masaki

Takata, ${ }^{\#}$ Roman Boca, ${ }^{\dagger+}$ Miki Hasegawa, ${ }^{\ddagger \ddagger}$ Kurt Mereiter, ${ }^{\S}$ Andrea Caneschi, ${ }^{\S \S}$ Wolfgang

$$
\text { Linert }^{*},+
$$

${ }^{\dagger}$ Institute of Applied Synthetic Chemistry, Vienna University of Technology, Getreidemarkt 9/163-AC, A1060 Vienna, Austria; " Department of Chemistry, University of Otago, PO Box 56, Dunedin, New Zealand; $\S$ Institute of Chemical Technologies and Analytics, Vienna University of Technology, Getreidemarkt 9/164-

SC, A-1060 Vienna, Austria;" JASRI/SPring-8, 1-1-1 Kouto, Sayo-gun, Hyogo 679-5198, Japan and CREST, JST; ${ }^{+\dagger}$ Institute of Inorganic Chemistry, Slovak Technical University, SK-812 37 Bratislava, Slovakia; ${ }^{\sharp \neq}$ College of Science and Engineering, Aoyama-Gakuin University, Sagamihara, Kanagawa 2298558, Japan; ${ }^{\S}$ LAMM, Dipartimento di Chimica \& UdR INSTM, Università di Firenze, Via della Lastruccia 3, I-50019 Sesto F.no, Italy

\section{Supporting Information}

Index

S1

S2

Mid FT-IR spectroscopy

S3-S8 $\quad X$-ray single crystal diffraction studies

S9-S11 Synchrotron powder diffraction

S12 Thermogravimetry

S13 Mössbauer spectroscopy

S14 Far FT-IR spectroscopy 
Table 1. Prominent Mid- FTIR Bands of $\left[\mathrm{Fe}(4 \mathrm{ditz})_{3}\right]\left(\mathrm{PF}_{6}\right)_{2} \cdot \mathrm{solv}^{\mathrm{a}}$ at RT.

${ }^{a}$ Frequencies in $\mathrm{cm}^{-1}: v$, stretching; $\delta$, deformation or in-plane vibration of the ring; $\gamma$, out-of-plane.

\begin{tabular}{|l|l|l|}
\hline & {$\left[\mathrm{Fe}(4 \mathrm{ditz})_{3}\right]\left(\mathrm{PF}_{6}\right)_{2} \cdot 0.075 \mathrm{MeOH}$} & {$\left[\mathrm{Fe}(4 \mathrm{ditz})_{3}\right]\left(\mathrm{PF}_{6}\right)_{2} \cdot 0.25 \mathrm{EtOH}$} \\
\hline$v(\mathrm{C}-\mathrm{H})$ & $3166 \mathrm{vs}$ & $3167 \mathrm{vs}$ \\
\hline$v(\mathrm{C}-\mathrm{H})$ & $2986 \mathrm{~m}, 2964 \mathrm{~m}, 2941 \mathrm{~m}, 2878 \mathrm{w}$ & $2990 \mathrm{~m}, 2964 \mathrm{~m}, 2942 \mathrm{~m}, 2879 \mathrm{w}$ \\
\hline aromatic overtone band & $1776 \mathrm{w}$ & $1774 \mathrm{w}$ \\
\hline$v\left(\mathrm{~N}_{2}=\mathrm{N}_{3}\right)\left\{+v\left(\mathrm{C}_{5}-\mathrm{N}_{1}\right)+v\left(\mathrm{C}_{\text {alkyl }}-\mathrm{N}_{1}\right)\right\}$ & $1507 \mathrm{vs}$ & $1508 \mathrm{vs}$ \\
\hline$\delta\left(\mathrm{C}-\mathrm{H}_{2}\right)$ & $1468 \mathrm{~s}, 1442 \mathrm{~m}$ & $1468 \mathrm{~s}, 1442 \mathrm{~m}$ \\
\hline$v\left(\mathrm{~N}_{1}-\mathrm{C}_{\text {alkyl }}\right)$ & $1382 \mathrm{~m}$ & $1383 \mathrm{~m}$ \\
\hline$\delta\left(\right.$ ring $\left._{1}\right)$ & $1244 \mathrm{w}$ & $1244 \mathrm{w}$ \\
\hline$v\left(\mathrm{C}=\mathrm{N}_{4}\right), v\left(\mathrm{~N}_{1}-\mathrm{N}_{2}\right)$ & $1179 \mathrm{vs}$ & $1180 \mathrm{vs}$ \\
\hline$v(\mathrm{C}-\mathrm{N}), \delta(\mathrm{C}-\mathrm{H})$ & $1097 \mathrm{~s}$ & $1097 \mathrm{~s}$ \\
\hline$v\left(\mathrm{~N}_{3}-\mathrm{N}_{4}\right)$ & $1026 \mathrm{~m}$ & $1026 \mathrm{~m}$ \\
\hline$\delta\left(\right.$ ring $\left._{2}\right)$ in plane bending $\{\delta(\mathrm{NCN})\}$ & $997 \mathrm{~s}$ & $998 \mathrm{~s}$ \\
\hline$\delta\left(\right.$ ring $\left._{3}\right)$ in plane bending $\{\delta(\mathrm{NCN})\}$ & $893 \mathrm{vs}$ & $893 \mathrm{vs}$ \\
\hline$v(\mathrm{P}-\mathrm{F})$ & $839 \mathrm{vs}$ & $840 \mathrm{vs}$ \\
\hline$\delta\left(\mathrm{C}-\mathrm{H}_{2}\right)$ & $718 \mathrm{~m}$ & $718 \mathrm{~m}$ \\
\hline$v\left(\right.$ ring $\left._{4}\right)$ out of plane & $662 \mathrm{~s}$ & $662 \mathrm{~s}$ \\
\hline$\delta(\mathrm{P}-\mathrm{F})$ & $558 \mathrm{vs}$ & $558 \mathrm{vs}$ \\
\hline
\end{tabular}




\section{Details of SQUID measurements:}

$\left[\mathrm{Fe}(4 \mathrm{ditz})_{3}\right]\left(\mathrm{PF}_{6}\right)_{2} \cdot 0.075 \mathrm{MeOH}$ :

Pascal's constants: $-465 \times 10^{-6} \mathrm{~cm}^{3} / \mathrm{mol}$

Sample weight: $7.73 \mathrm{mg}$

Molecular mass: 930.77 a.m.u.

$\left[\mathrm{Fe}(4 \mathrm{ditz})_{3}\right]\left(\mathrm{PF}_{6}\right)_{2} \cdot 0.25 \mathrm{EtOH}:$

Pascal's constants: $-470 \times 10^{-6} \mathrm{~cm}^{3} / \mathrm{mol}$

Sample weight: $16.0 \mathrm{mg}$

Molecular mass: 939.89 a.m.u. 


\section{$X$-ray single crystal diffraction studies}

Suitable crystals of $\left[\mathrm{Fe}(4 \mathrm{ditz})_{3}\right]\left(\mathrm{PF}_{6}\right)_{2}$.solv obtained by the diffusion method were removed from the mother liquor, covered by high viscosity perfluorpolyether (Sigma-Aldrich Fomblin Y Hvac 140/13) and then instantly transferred to a Bruker Smart APEX CCD 3-axis diffractometer equipped with a Bruker Kryo-flex cooling unit. X-ray data were collected at $\mathrm{T}=100 \mathrm{~K}$ using graphite-monochromated Mo Ka radiation $(\lambda=$ $0.71073 \AA$ ) and $0.3^{\circ} \omega$-scan frames covering either complete spheres or hemispheres of the reciprocal space. Each two separate crystals grown from methanol and from ethanol were measured in order to have a check for reproducibility of critical results, in particular the solvent electron density distribution. After data integration, corrections for absorption, $\lambda / 2$ effects, and system instability were applied. ${ }^{1}$ The structures were refined on $F^{2}$ with the program SHELXL97 ${ }^{2}$ using the starting parameters ${ }^{3}$ for the non-solvent part of the structure, with anisotropic thermal displacement parameters for the non-hydrogen atoms and hydrogen atoms with isotropic displacement parameters treated as riding. Then the solvent containing part of the structure was analyzed by difference Fourier syntheses and solvent peaks were inserted in the refinement varying $x, y, z, U_{\mathrm{ij}}$ and site occupation factors for them. The final assignment of these peaks to carbon and oxygen atoms was based on the condition that the population parameters of the solvent peaks should reflect the solvent composition, i.e. the ratios of population parameters weighted by site multiplicities should be close to 1:1 in C:O for methanol, and 2:1 for ethanol. Due to the distinctly different numbers of electrons -6 per carbon, 8 per oxygen - a reasonable distinction of $\mathrm{C}$ and $\mathrm{O}$ was possible assuming the water content of the samples to be low. Crystal data and experimental details for the two methanol solvate and the two ethanol solvate crystals are given in Table S2, further information including atomic parameters can be found in the supporting CIF. One important and unambiguous result of the single crystal X-ray diffraction study was, that the crystals obtained from methanol and ethanol showed practically identical host lattices, but displayed distinctly different solvent electron densities within the structural cavity centered at $0,0,1 / 2$. The methanol solvate has a pronounced electron density maxmimum at the special position $x, y, z=0,0,1 / 2$ (Wyckoff position $1 \mathrm{~b}$, point symmetry $\overline{3}$ ) which is surrounded by six symmetry equivalent peaks in general position $[x, y, z=0.1488(9), 0.0814(12), 0.5129(11)$; Wyckoff position $6 \mathrm{~g}$, point symmetry 1] forming a slightly undulated hexagon with an edge length of $1.433 \AA$ and a distance to the central peak of $1.420 \AA$. In contrast to this, the ethanol solvate has no peak in electron density at $x, y, z=0,0,1 / 2$ rather than a minimum, whereas 6 symmetry equivalent electron density peaks 
are at $x, y, z=0.044(8), 0.073(3), 0.500(4)$ forming a perfectly flat hexagon with an edge length of $0.70 \AA$. In addition there is an outer set of six symmetry equivalent peaks $[x, y, z=0.171(4) 0.111(3) 0.535(4)$; Wyckoff position $6 \mathrm{~g}$, point symmetry 1] forming a cyclohexane-like puckered ring with an edge length of $1.758 \AA$ and a central distance (to $0,0,1 / 2$ ) of $1.677 \AA$. Two sections of the solvent electron density maps are given in the main part of the paper. Further visualizations of the solvent peaks and their environment are shown in Figures $\mathrm{S} 1$ and 2., 5

\section{References:}

[1] Bruker programs: SMART, version 5.629; SAINT, version 6.54; SADABS version 2.10; XPREP, version 6.14; SHELXTL, version 6.14. Bruker AXS Inc.: Madison, WI, 2003.

[2] Sheldrick, G. M. SHELX97: Program System for Crystal Structure Determination; University of Göttingen: Göttingen, Germany, 1997.

[3] Grunert, C.M. ; Schweifer, J. ; Weinberger, P. ; Linert, W.; Mereiter, K.; Hilscher, G.; Mueller, M.; Wiesinger, G.; van Koningsbruggen, P.J. Inorg. Chem. 2004, 43, 155-165.

[4] A.L.Spek (2005) PLATON, A Multipurpose Crystallographic Tool, Utrecht University, Utrecht, The Netherlands.

[5] Program MERCURY: visualization and analysis of crystal structures. C. F. Macrae, P. R. Edgington, P. McCabe, E. Pidcock, G. P. Shields, R. Taylor, M. Towler and J. van de Streek, J. Appl. Cryst., 39, 453-457, 2006. 
Table 2. Details for the crystal structure determinations of $\left[\mathrm{Fe}(4 \mathrm{ditz})_{3}\right]\left(\mathrm{PF}_{6}\right)_{2}$.solv.

\begin{tabular}{|c|c|c|c|c|}
\hline Crystal data & & & & \\
\hline Local compound code & 1130 methanol solvate & 1124 methanol solvate & 1102 ethanol solvate & 1098 ethanol solvate \\
\hline formula & $\begin{array}{l}\mathrm{Fe}(4 \mathrm{ditz})_{3}\left(\mathrm{PF}_{6}\right)_{2} \cdots- \\
0.75\left(\mathrm{CH}_{3} \mathrm{OH}\right)\end{array}$ & $\begin{array}{l}\mathrm{Fe}(4 \mathrm{ditz})_{3}\left(\mathrm{PF}_{6}\right)_{2} \cdots- \\
0.75\left(\mathrm{CH}_{3} \mathrm{OH}\right)\end{array}$ & $\begin{array}{l}\mathrm{Fe}(4 \mathrm{ditz})_{3}\left(\mathrm{PF}_{6}\right)_{2} \cdots- \\
0.25\left(\mathrm{C}_{2} \mathrm{H}_{5} \mathrm{OH}\right)\end{array}$ & $\begin{array}{l}\mathrm{Fe}(4 \mathrm{ditz})_{3}\left(\mathrm{PF}_{6}\right)_{2} \cdots- \\
0.25\left(\mathrm{C}_{2} \mathrm{H}_{5} \mathrm{OH}\right)\end{array}$ \\
\hline fw & 952.48 & 952.48 & 939.97 & 939.97 \\
\hline cryst.size, mm & $0.35 \times 0.27 \times 0.15$ & $0.58 \times 0.34 \times 0.28$ & $0.28 \times 0.24 \times 0.15$ & $0.32 \times 0.24 \times 0.18$ \\
\hline space group & $P \overline{3}$ (no. 147) & $P \overline{3}$ & $P \overline{3}$ & $P \overline{3}$ \\
\hline $\mathrm{a}, \AA$ & $10.9686(3)$ & $10.963(2)$ & $10.9726(4)$ & $10.9697(5)$ \\
\hline $\mathrm{c}, \AA$ & $8.6941(5)$ & $8.6978(16)$ & $8.6916(7)$ & $8.6824(8)$ \\
\hline$V, A^{3}$ & $905.85(6)$ & $905.4(3)$ & $906.25(9)$ & $904.81(10)$ \\
\hline Z & 1 & 1 & 1 & 1 \\
\hline$\rho_{\text {calc }}, \mathrm{g} \mathrm{cm}^{-3}$ & 1.746 & 1.747 & 1.722 & 1.725 \\
\hline $\mathrm{T}, \mathrm{K}$ & $100(2)$ & $100(2)$ & $100(2)$ & $100(2)$ \\
\hline$\mu, \mathrm{mm}^{-1}(\mathrm{Mo} \mathrm{K \alpha})$ & 0.625 & 0.625 & 0.622 & 0.623 \\
\hline$F(000)$ & 484 & 484 & 477 & 477 \\
\hline$\theta_{\text {max }}$, deg & 29.9 & 29.9 & 29.9 & 29.9 \\
\hline no. of rflns measd & 7057 & 7445 & 10297 & 3848 \\
\hline no. of unique rflns & 1762 & 1766 & 1768 & 1559 \\
\hline no. of rflns $\mid>2 \sigma(I)$ & 1753 & 1646 & 1611 & 1420 \\
\hline no. of params & 100 & 99 & 106 & 106 \\
\hline$R_{1}(I>2 \sigma(I))^{[a]}$ & 0.0215 & 0.0307 & 0.0293 & 0.0333 \\
\hline $\mathrm{R}_{1}$ (all data) & 0.0216 & 0.0332 & 0.0334 & 0.0372 \\
\hline $\mathrm{wR}_{2}$ (all data) & 0.0553 & 0.0798 & 0.0766 & 0.0803 \\
\hline $\begin{array}{l}\text { Diff.Four.peaks } \\
\min / \max , \AA^{-3}\end{array}$ & $-0.25 / 0.41$ & $-0.37 / 0.62$ & $-0.19 / 0.53$ & $-0.22 / 0.62$ \\
\hline & & & & \\
\hline
\end{tabular}




\begin{tabular}{|c|c|c|c|c|}
\hline Geometric data & 1130 methanol solvate & 1124 methanol solvate & 1102 ethanol solvate & 1098 ethanol solvate \\
\hline $\mathrm{Fe}-\mathrm{N}(4) \quad(6 \mathrm{x})$ & $1.9905(8)$ & $1.9931(9)$ & $1.9918(9)$ & $1.9923(11)$ \\
\hline N1-N2 & $1.3456(12)$ & $1.3450(14)$ & $1.3463(14)$ & $1.3467(16)$ \\
\hline N2-N3 & $1.2921(12)$ & $1.2939(14)$ & $1.2924(14)$ & $1.2920(16)$ \\
\hline N3-N4 & $1.3642(12)$ & $1.3615(13)$ & $1.3621(13)$ & $1.3603(16)$ \\
\hline $\mathrm{N} 4-\mathrm{C} 1$ & $1.3271(12)$ & $1.3239(14)$ & $1.3265(14)$ & $1.3264(16)$ \\
\hline $\mathrm{N} 1-\mathrm{C} 1$ & $1.3331(13)$ & $1.3315(14)$ & $1.3310(14)$ & $1.3305(17)$ \\
\hline $\mathrm{N} 1-\mathrm{C} 2$ & $1.4699(13)$ & $1.4692(14)$ & $1.4704(14)$ & $1.4690(16)$ \\
\hline $\mathrm{C} 2-\mathrm{C} 3$ & $1.5216(14)$ & $1.5230(15)$ & $1.5240(15)$ & $1.519(2)$ \\
\hline C3-C3 & $1.5344(18)$ & $1.529(2)$ & $1.530(2)$ & $1.532(3)$ \\
\hline P-F1 (3x) & $1.6060(8)$ & $1.6044(9)$ & $1.6048(8)$ & $1.6030(10)$ \\
\hline P-F2 (3x) & $1.6005(9)$ & $1.5993(9)$ & $1.6001(9)$ & $1.5992(11)$ \\
\hline $\mathrm{C} 1 \mathrm{~s}-\mathrm{O} 1 \mathrm{~s} / \mathrm{C} 1 \mathrm{~s}-\mathrm{C} 1 \mathrm{~s}$ & $1.420(9)$ & $1.404(11)$ & $1.27(8) / 1.40(5)$ & $1.29(12) / 1.43(7)$ \\
\hline $\begin{array}{l}\mathrm{x}, \mathrm{y}, \mathrm{z} \text {, and population } \\
\text { parameter of } \mathrm{C} 1 \mathrm{~s}\end{array}$ & $0, \quad 0, \quad 0.5, \quad 0.786(17)$ & $0,0,0.5, \quad 0.766(16)$ & $\begin{array}{l}0.044(8), \quad 0.073(3), \\
0.500(4), \quad 0.085(5)\end{array}$ & $\begin{array}{l}0.044(11), \quad 0.075(4), \\
0.501(6), \quad 0.084(7)\end{array}$ \\
\hline $\begin{array}{l}\mathrm{x}, \mathrm{y}, \mathrm{z} \text {, and population } \\
\text { parameter of } \mathrm{O} 1 \mathrm{~s}{ }^{[\mathrm{b}]}\end{array}$ & $\begin{array}{l}0.1488(9), \quad 0.0814(12) \\
0.5129(11), \quad 0.131(3)\end{array}$ & $\begin{array}{ll}0.1473(12), & 0.0799(13) \\
0.5118(12), & 0.128(3)\end{array}$ & $\begin{array}{ll}0.171(4), & 0.111(3) \\
0.535(4), & 0.043(3)\end{array}$ & $\begin{array}{ll}0.171(4), & 0.108(4), \\
0.535(4), & 0.042(3)\end{array}$ \\
\hline $\begin{array}{l}\text { Refined solvent content } \\
\text { per cavity and } \mathrm{Fe} \text {, in \% }\end{array}$ & $79(2)$ & $77(2)$ & $26(2)$ & $25(2)$ \\
\hline
\end{tabular}

${ }^{\text {[a] }} \mathrm{R}_{1}=\Sigma|| \mathrm{F}_{\mathrm{o}}|-| \mathrm{F}_{\mathrm{c}}|| / \Sigma\left|\mathrm{F}_{\mathrm{o}}\right|, w \mathrm{R}_{2}=\left[\Sigma\left(w\left(\mathrm{~F}_{\mathrm{o}}^{2}-\mathrm{F}_{\mathrm{c}}{ }^{2}\right)^{2}\right) / \Sigma\left(w\left(\mathrm{~F}_{\mathrm{o}}{ }^{2}\right)^{2}\right]^{1 / 2}\right.$

${ }^{[b]} \mathrm{C} 1 \mathrm{~s}$ and $\mathrm{O} 1 \mathrm{~s}$ are the partially occupied solvent peaks. 
Fig. 1. Projection of the unit cell of $\left[\mathrm{Fe}(4 \mathrm{ditz})_{3}\right]\left(\mathrm{PF}_{6}\right)_{2}$.solv down the $c$-axis showing the solvent cavities as violet circular disks lying above the $\mathrm{FeN}_{6}$ ocathedra. The size of the disks corresponds approximately to the van der Waals surfaces of the host lattice. Color scheme: carbon black, nitrogen blue, phosphorus yellow, fluorine red.

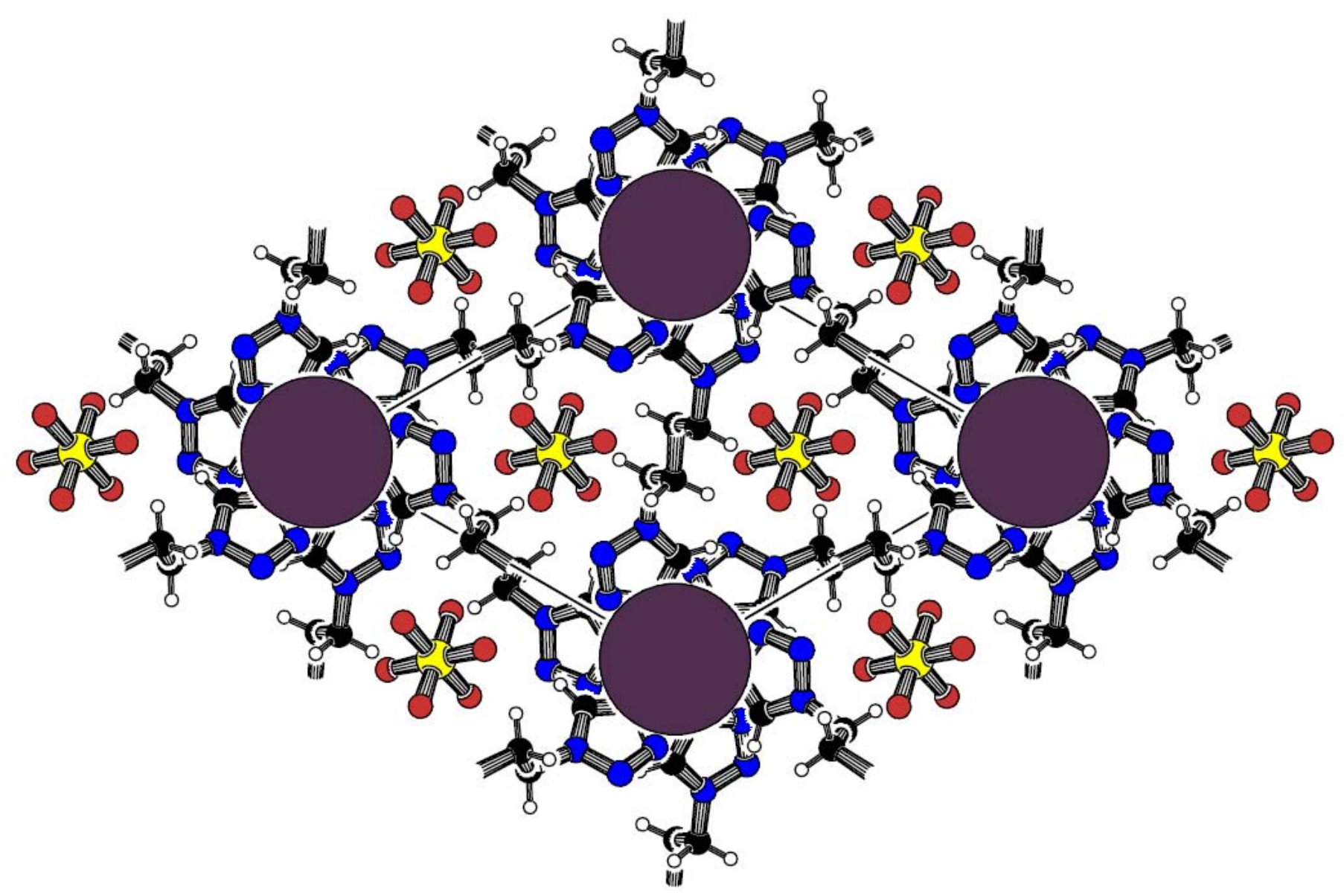


Fig. 2. Spatial arrangement of the solvent peaks of $\left[\mathrm{Fe}(4 \mathrm{ditz})_{3}\right]\left(\mathrm{PF}_{6}\right)_{2}$. solv of one solvent cavity in various representations. View direction is almost perpendicular to the $c$-axis which runs up-down. Left figure: capped sticks with grey spheres for solvent carbon and red spheres for solvent oxygens, hydrogen atoms omitted.

Central figure: Space filling diagram including hydrogen atoms.

Right figure: Space filling diagram with upper $\mathrm{FeN}_{6}$ octahedron removed.

(A) methanol solvate
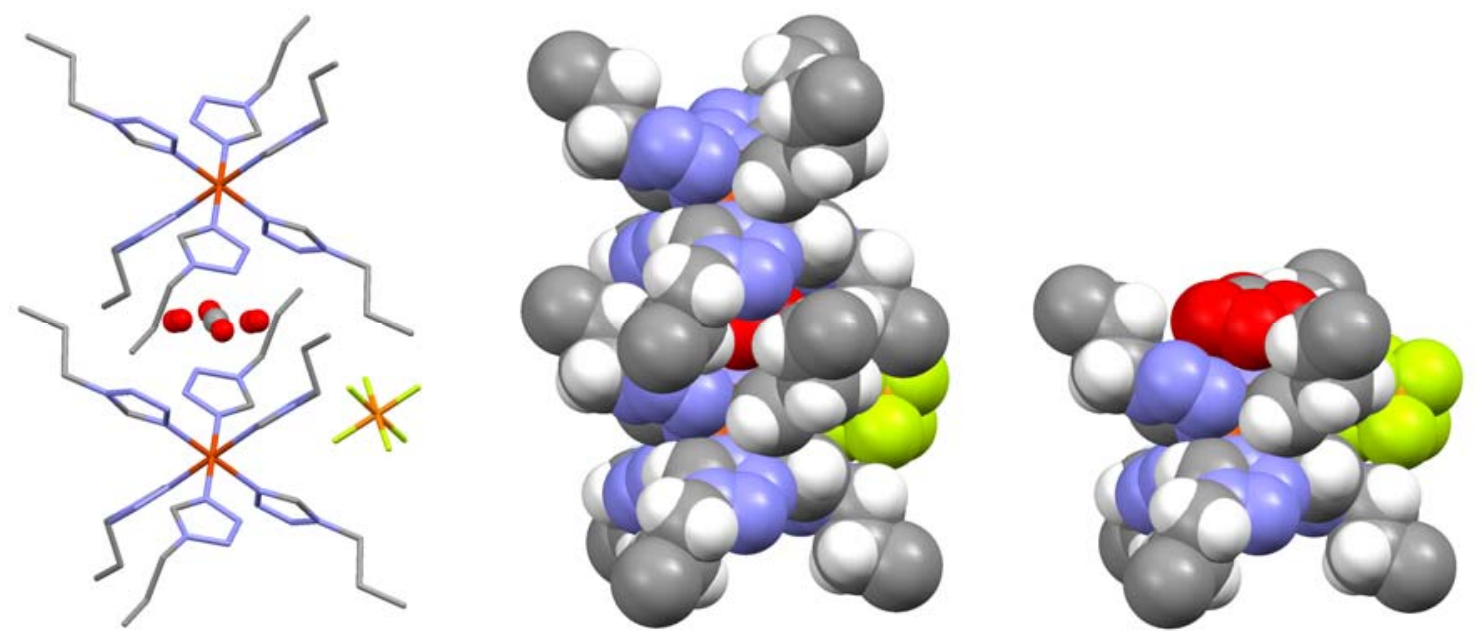

(B) ethanol solvate
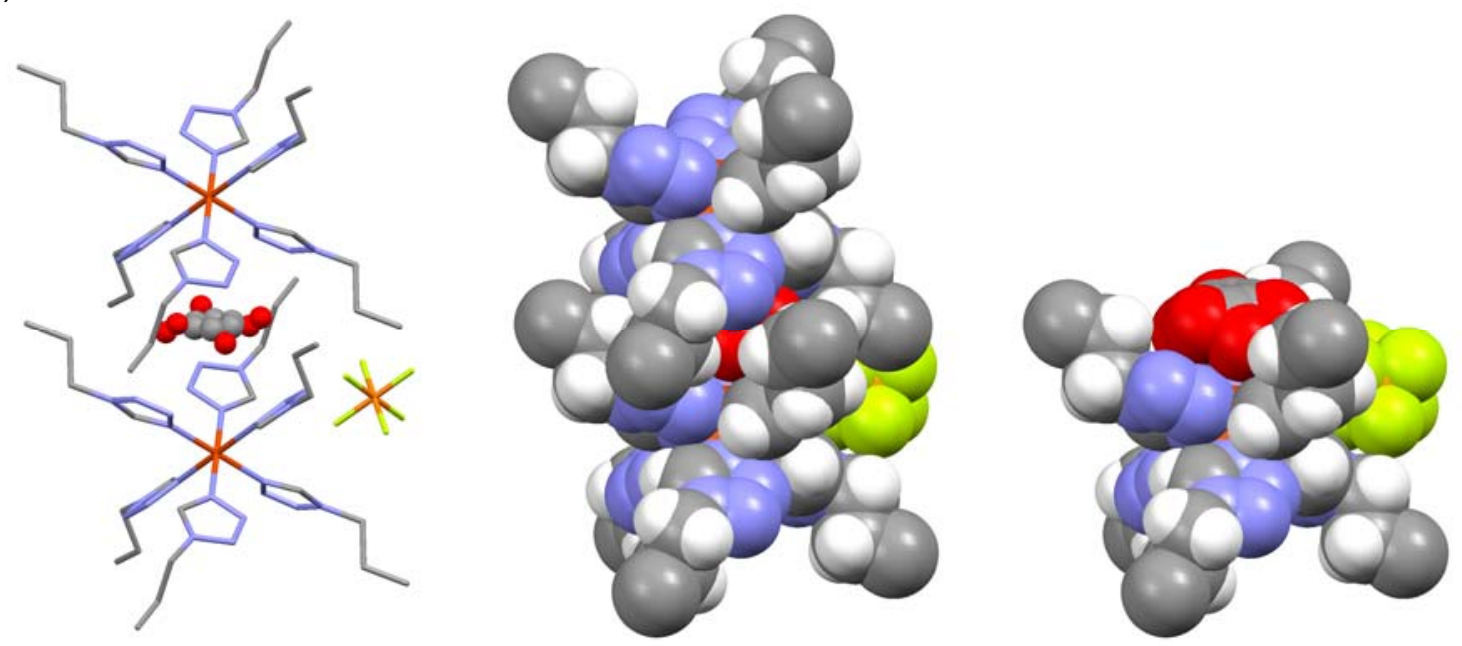


\section{Le Bail refinement of the synchrotron powder diffraction patterns}

In a typical Le Bail fitting procedure the background was set manually firstly. As synchrotron radiation was used the Cagliotti parameters were fixed to $U=V=W=0$ for the whole refinement as well as the sample

shift, transparency, $X_{\mathrm{e}}$ and $X_{\mathrm{s}}$. The microstrain broadening coefficients were set to zero in the beginning of the refinement. The remaining profile parameters, $P, X, S / L$ and $H / L$, were assigned starting values obtained from a previous refinement of a $\mathrm{CeO}_{2}$ standard. Then the lattice parameters and zero shift were allowed to vary. In the second stage the parameters affecting the particle size $(P, X)$ were released, indicating pure gaussian size broadening, i.e. $X=0$. The absence of reflection asymmetry was confirmed by low $S / L$ and $H / L$ that were virtually zero and therefore kept fixed at this value. The introduction of microstrain was set in by assigning the mixing coefficient $\eta$ the constant 0.75 . Then the broadening parameters were released in the following order in sequent refinement cycles: S400 - S004 - S202 S211. In the last stage $\eta$ was allowed to vary additionally giving 9 refined parameters in total. In the case of the $\mathrm{MeOH}$-solvate at $175 \mathrm{~K}$ (Table S3) the profile shape parameters of the two phases were constrained. 
Table 3. Lattice and profile parameters obtained by Le Bail extraction for $\left[\mathrm{Fe}(4 \mathrm{ditz})_{3}\right]\left(\mathrm{PF}_{6}\right)_{2} \cdot 0.25 \mathrm{EtOH}$ at $100 \mathrm{~K}(\lambda=1.00119 \AA$, SG $P \overline{3}$ (No. 147))

\section{Crystal parameters}

$$
\begin{array}{rr}
\text { Lattice parameters }[\AA] a=b & 10.98476(5) \\
c & 8.68518(7)
\end{array}
$$

\section{Profile parameters}

$$
\begin{array}{rl}
\text { Zero shift } & -0.00412(6) \\
S_{s}=T_{s} & 0 \text { (fixed) } \\
U=V=W & 0 \text { (fixed) } \\
X=X_{\mathrm{e}}=X_{s} & 0 \text { (fixed) } \\
S / L=H / L & 5 \cdot 10^{-4} \text { (fixed) } \\
P & 2.22(1) \\
\eta & 0.679(5) \\
S 400 & 0.0308(5) \\
S 004 & 0.086(2) \\
S 202 & 0.0052(7) \\
S 211 & 0.016(1)
\end{array}
$$

\section{Agreement indices}

$$
\begin{array}{rl}
R_{\mathrm{p}} & 0.0357 \\
R_{\mathrm{wp}} & 0.0486 \\
R_{\text {exp }} & 0.0364 \\
\chi^{2} & 1.78
\end{array}
$$


Table 4. Temperature-dependent lattice parameters $[\AA]$ and unit cell volumes $\left[\AA^{3}\right]$ of the $\left[\mathrm{Fe}(4 \mathrm{ditz})_{3}\right]\left(\mathrm{PF}_{6}\right)_{2^{-}}$ solvates (SG $P \overline{3}$ (No. 147))

\begin{tabular}{|c|c|c|c|}
\hline$T[\mathrm{~K}]$ & $a=b$ & c & $v$ \\
\hline \multicolumn{4}{|l|}{ MeOH/cooling } \\
\hline 300 & $11.23659(6)$ & $8.89165(8)$ & $972.26(1)$ \\
\hline 200 & $11.22928(7)$ & $8.84687(9)$ & $966.10(2)$ \\
\hline $175^{a}$ & $11.10218(5)$ & $8.76179(7)$ & $935.28(1)$ \\
\hline $175^{a}$ & $10.9827(2)$ & $8.6836(4)$ & $907.08(3)$ \\
\hline 150 & $10.97084(4)$ & $8.67510(6)$ & $904.24(1)$ \\
\hline 125 & $10.96729(4)$ & $8.66986(6)$ & 903.11(1) \\
\hline 100 & $10.96420(4)$ & $8.66534(6)$ & $902.13(1)$ \\
\hline \multicolumn{4}{|l|}{ MeOH/heating } \\
\hline 150 & $10.97304(4)$ & $8.67772(6)$ & $904.88(1)$ \\
\hline $175^{b}$ & $11.10491(6)$ & $8.76610(8)$ & $936.20(1)$ \\
\hline $175^{b}$ & $10.98561(7)$ & $8.68749(9)$ & $907.97(1)$ \\
\hline 200 & $11.23111(7)$ & $8.85039(9)$ & $966.80(2)$ \\
\hline 300 & $11.24335(6)$ & $8.89687(8)$ & $974.00(1)$ \\
\hline \multicolumn{4}{|l|}{ EtOH/cooling } \\
\hline 300 & $11.25333(7)$ & $8.90248(9)$ & $976.35(2)$ \\
\hline 250 & $11.25189(7)$ & $8.88389(9)$ & $974.06(2)$ \\
\hline 200 & $11.24439(7)$ & $8.86039(9)$ & $970.19(2)$ \\
\hline 175 & $11.12682(6)$ & $8.78152(8)$ & $941.55(1)$ \\
\hline 150 & $10.99430(5)$ & $8.69712(7)$ & $910.42(1)$ \\
\hline 125 & $10.98858(5)$ & $8.69034(6)$ & $908.76(1)$ \\
\hline 100 & $10.98476(5)$ & $8.68518(7)$ & $907.59(1)$ \\
\hline 50 & $10.98162(6)$ & $8.68063(8)$ & $906.60(1)$ \\
\hline 9 & $10.97831(8)$ & $8.67906(1)$ & $905.89(2)$ \\
\hline \multicolumn{4}{|l|}{ EtOH/heating } \\
\hline 50 & $10.98181(6)$ & $8.68126(8)$ & $906.70(1)$ \\
\hline 200 & $11.25570(6)$ & $8.89304(9)$ & $975.72(2)$ \\
\hline 300 & $11.25626(7)$ & $8.91149(9)$ & $977.84(2)$ \\
\hline \multicolumn{4}{|l|}{${ }^{a}$ Two-phase mixture } \\
\hline${ }^{\mathrm{b}}$ Two-phase mixture & & & \\
\hline
\end{tabular}


Fig. 3. Thermogravimetry of $\left[\mathrm{Fe}(4 \mathrm{ditz})_{3}\right]\left(\mathrm{PF}_{6}\right)_{2}$.solv

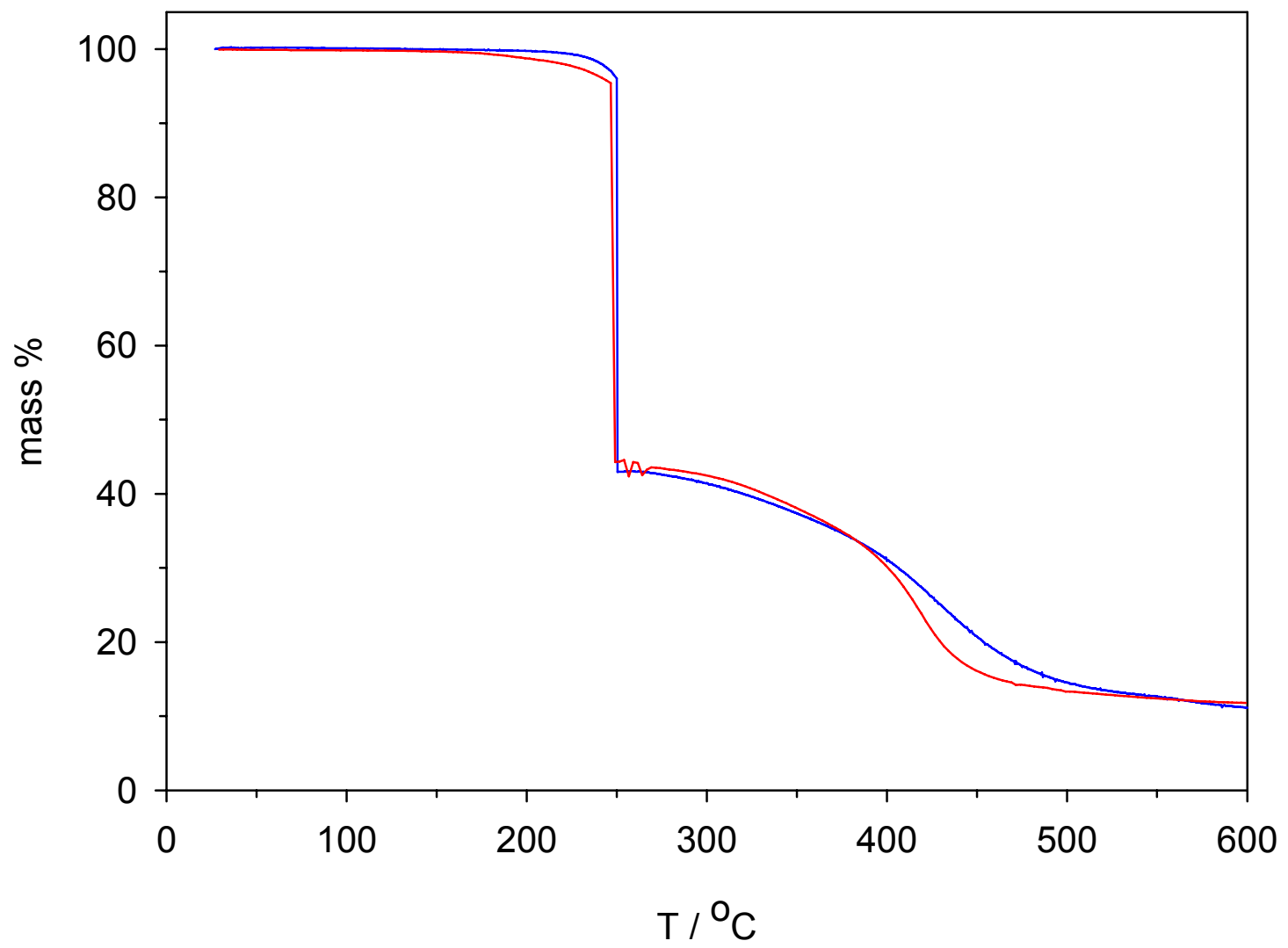

Thermogravimetry of $\left[\mathrm{Fe}(4 \mathrm{ditz})_{3}\right]\left(\mathrm{PF}_{6}\right)_{2} \cdot 0.075 \mathrm{MeOH}(-)$ and $\left[\mathrm{Fe}(4 \mathrm{ditz})_{3}\right]\left(\mathrm{PF}_{6}\right)_{2} \cdot 0.25 \mathrm{EtOH}(-)$. The experiments were performed on a Netzsch TG-209 analyzer within the temperature range of $25-600{ }^{\circ} \mathrm{C}$ at a heating rate of $5^{\circ} \mathrm{C} \mathrm{min}^{-1}$. 
Fig. 4. Mössbauer Spectra of $\left[\mathrm{Fe}(4 \mathrm{ditz})_{3}\right]\left(\mathrm{PF}_{6}\right)_{2} \cdot 0.25 \mathrm{EtOH}$

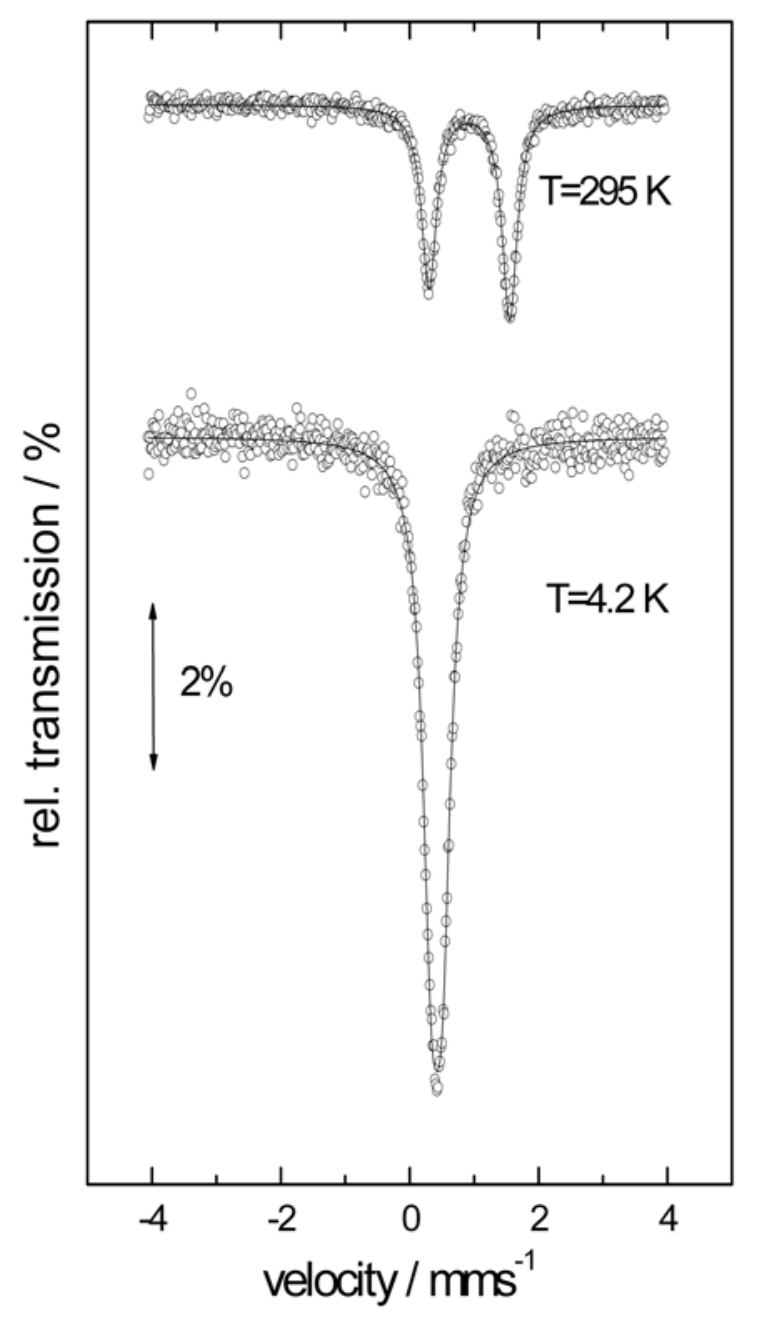

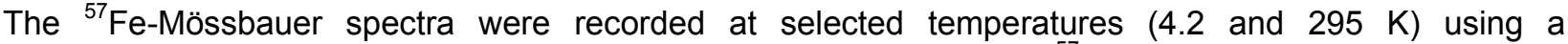
conventional constant acceleration drive system. The source used was ${ }^{57} \mathrm{Co}$ in a Rh-matrix with an activity of about $50 \mathrm{mCi}$. The data were analyzed using a least-squares fitting program assuming Lorentzian lines. 
Fig. 5. Far-FTIR spectra of $\left[\mathrm{Fe}(4 \mathrm{ditz})_{3}\right]\left(\mathrm{PF}_{6}\right)_{2}$.solv at $\mathrm{RT}$ and $100 \mathrm{~K}$.

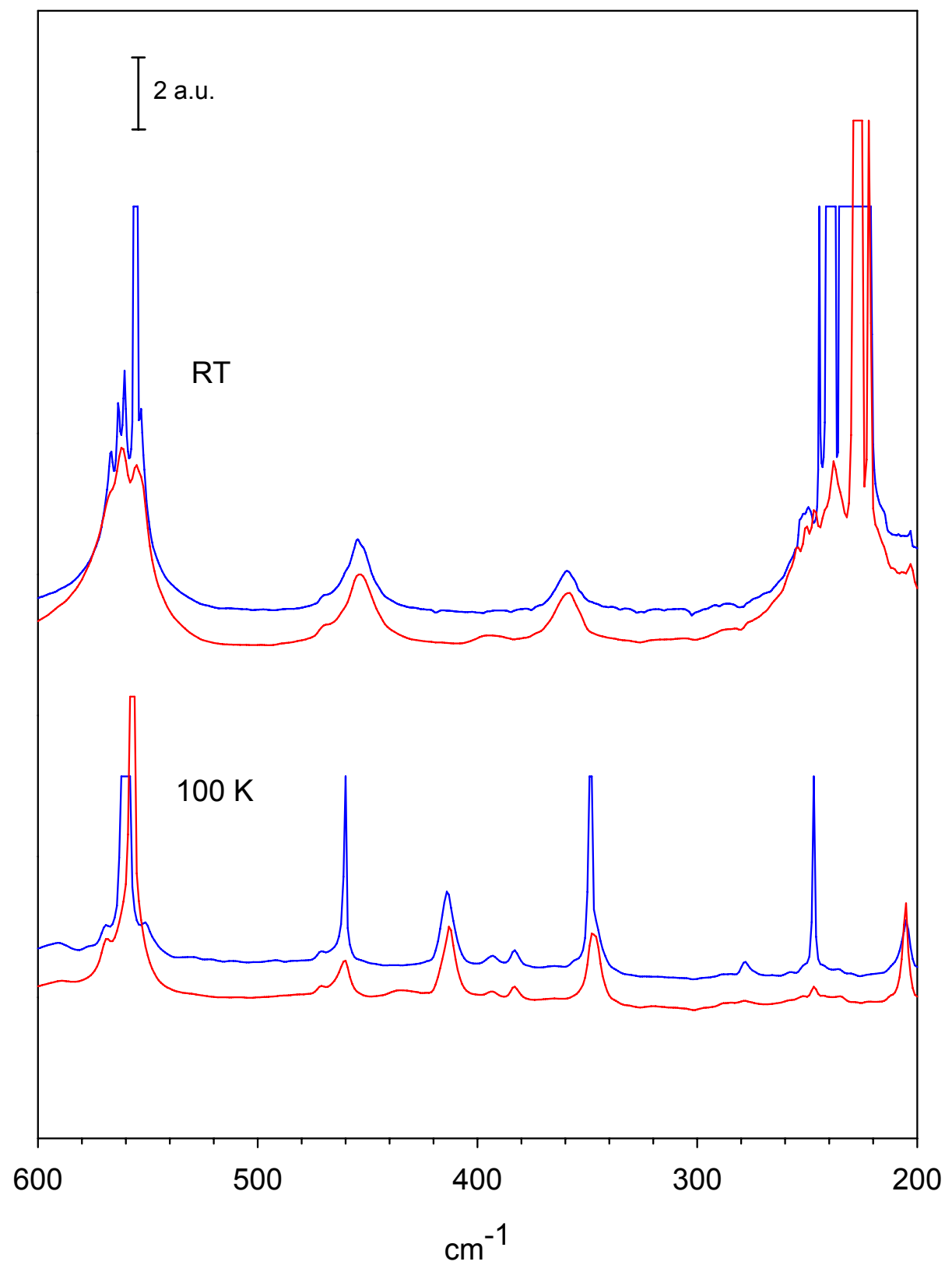

Far-IR spectra of $\left[\mathrm{Fe}(4 \mathrm{ditz})_{3}\right]\left(\mathrm{PF}_{6}\right)_{2} \cdot 0.075 \mathrm{MeOH}(-)$ and $\left[\mathrm{Fe}(4 \mathrm{ditz})_{3}\right]\left(\mathrm{PF}_{6}\right)_{2} \cdot 0.25 \mathrm{EtOH}(-)$ at $\mathrm{RT}$ and $100 \mathrm{~K}$. The spectra have been normalized to the methanolate bands at $455 \mathrm{~cm}^{-1}$ at RT and $413 \mathrm{~cm}^{-1}$ at $100 \mathrm{~K}$ to allow comparison. The bands at ca. $570 \mathrm{~cm}^{-1}$ are caused by $\mathrm{PF}_{6}^{-}$vibrations and those below 250 $\mathrm{cm}^{-1}$ are lattice vibrations. The spectra were recorded within the range $600-200 \mathrm{~cm}-1$ on a Perkin-Elmer System 2000 far-FTIR spectrometer. The coordination polymers were diluted with polyethylene and pressed at a pressure of $10,000 \mathrm{kgcm}^{-2}$ transiently. Variable-temperature far-FTIR spectra in the temperature range 100-298 K were recorded with a Graseby-Specac thermostattable sample holder with polyethylene windows, attached to a Graseby-Specac automatic temperature controller. 